\title{
REPATRIATION OF MIGRANTS TO ISIS: THE EXPERIENCE OF FOUR STATES FROM THE WESTERN BALKANS
}

\author{
Tatyana DRONZINA \\ Full professor at the Department of political science of Sofia University St. \\ Kliment Ohridski, Bulgaria \\ E-mail: dronzina@phls.uni-sofia.bg
}

Akmaral MEDIKHANOVA

Associated professor at the Department of International Relations, Yessenov

University, Kazakhstan

E-mail: akmaral.medikhanova@yu.edu.kz

\begin{abstract}
This article is about the repatriation of migrants to ISIS by four countries of the Western Balkans: Albania, BiH, Kosovo and Republic of North Macedonia. The main research question is: under which conditions States are prone to repatriate their nationals in ISIS? It is argued that the likelihood of undertaking such a step is higher where there is a constellation of strong internal number of migrants, secular-oriented Muslim population, government messages, suitable legislation, interinstitutional and intersectoral cooperation, participation of civil society) and external incentives (desire to prove oneself as a reliable international partner, membership in international organizations, international cooperation in repatriation operations).
\end{abstract}

Key words: ISIS, repatriation, Albania, Bosnia and Herzegovina, Kosovo, Republic of North Macedonia

\section{Methodology and terminology}

Recently, the issue of repatriation has become relevant in the context of the military defeat of ISIS. The terrorist organization emerged from the remnants of al Qaeda in Iraq (AQI), and its transformation into pseudo-State (Caliphate) led to a huge concentration of foreign fighters, which, although impressive, is far to be the first. (Donnelly, M, Sanderson, T. \& Fellman, Z., 2017). Historically, the question how to call the foreigners in violent conflicts was never asked. In ISIS, however, they belong to different categories. To refer to personalities who took part in armed activities, we will use the term "foreign fighters" or "foreign terrorist fighters", as both are related to the practice of the 
UN Security Council and international humanitarian law. This concept is also used by the OSCE: "While the definition and scope of the term "foreign terrorist fighter" (FTF) is controversial, in recent years it has been commonly used to refer to individuals who have travelled from their home states to other states to participate in or support terrorist acts, including in the context of armed conflict, especially in Iraq and Syria" (OSCE, 2018). Along with them, there were also males and females employed in the civilian sphere, such as doctors, engineers, experts in Islamic law, telecommunications, etc. Several male militants and non-militants left for the Caliphate with their wives and children. We will call "migrants" all persons in the territory of the Islamic State of non-Syrian and non-Iraqi origin, regardless of their gender, age, and occupation, who joined it and, voluntarily or compulsorily, for certain time, obeyed its laws. (Dronzina, T. \& Medikhanova, A., 2021).

Currently, huge number of migrants are detainees in the prisons and camps of Syria and Iraq. Most countries are reluctant to repatriate their citizens. Four small nations from the Northern Balkans - Albania, Bosnia and Herzegovina $(\mathrm{BiH})$, Kosovo, Republic of North Macedonia are among those that did so. Why did they decide to take such a step despite of serious economic and political challenges they face, while other States with consolidated democratic systems and much more resources did not? We argue that the decision of repatriation is made under the impact of a constellation of strong internal (number of migrants, secular-oriented Muslim population, government messages, suitable legislation, interinstitutional and intersectoral cooperation, participation of civil society) and external incentives (desire to prove oneself as a reliable international partner, membership in international organizations, international cooperation in repatriation operations). It is not our purpose to analyze in depth any of these variables - there are abundant resources developed by national and international scholars and research teams. In our paper, they are presented rather schematically. What we aim is to identify their impact on the decision of repatriation.

Who are the persons who were and - hopefully - will be repatriated? Refugees? Internally displaced persons? Prisoners of war? Unlawful combatants? Detainees? The answer to this question - when it comes to the Islamic State - is neither simple, nor evident. International law can help, but it does not resolve all the doubts - "the answer to IAC [international armed conflicts] detention questions is necessary grounded in policy, not law" (Jenks, 2016).

Those who are supposed to be foreign terrorist fighters are imprisoned in several facilities without reliable mechanisms to distinguish between people who have taken part in the atrocities of ISIS and persons whose guilt has not been proven. During a visit in a prison in 2019, a journalist of the National Public Radio wrote that the facility director was not even sure who all the inmates were, since most of them had not even been interrogated (Arraf, 2019). The Washington Post stated that there is much that is not known about these prisons. (Berger, 2019). Envisaging the conditions in the places of detention, the French journalist Nicolas Hénin wrote for the US Institute of Peace web 
page the following: "...some argue that vengeance is justified, in part to protect ISIS' victims. As a former ISIS hostage painfully familiar with that brutality, I must reply that our only viable path is to bring these fighters home to face justice in courts of law" (Hénin, 2021).

Family members of foreign fighters and male foreigners practicing civic professions are often qualified as refugees or displaced persons. The UN gives a clear definition of this category of people: "the term 'refugee' shall apply to any person who...owing to wellfounded fear of being persecuted for reasons of race, religion, nationality, membership of a particular social group or political opinion, is outside the country of his nationality and is unable or, owing to such fear, is unwilling to avail himself of the protection of that country; or who, not having a nationality and being outside the country of his former habitual residence as a result of such events, is unable or, owing to such fear, is unwilling to return to it" (Refugees and Displaced Persons 62 (I), 1946). The 1951 Refugee Convention and the 1967 Protocol give States the right to designate persons who fall under the category of refugees following their own legal systems (UNHCR, Convention and Protocol Relating to the Status of Refugees, 1951, 1967). The Geneva convention (IV) contains an article specifically devoted to refugees and internally displaced persons (article 44, p, 33). (Geneva Convention (IV) relative to the Protection of Civilian Persons in Times of War, 1949). Additional Protocol I (1977) (Protocol additional to the Geneva conventions of 12 august 1949, and relating to the protection of victims of international armed conflicts, 1977) provides that refugees and stateless persons enjoy protection in accordance with Sections I, III, and IV of the Convention. Refugees "should be assisted by international action, either to return to their countries of nationality or former habitual residence, or to find new homes elsewhere" (Constitution of the International Refugee Organization, 1946). Migrants to ISIS can hardly be defined as refugees in the proper sense of the word - they escape a conflict in the territory of a pseudoState that does not exist anymore. Some of them remain loyal supporters of the terrorist group and would take any opportunity to work for its restoration, if such an opportunity appears. And finally, we still do not know if Baghuz exit was an exit of civilians from the atrocities of the war, or calculated decision to preserve the safety of foreign fighters' families and organization's capabilities.

By the same token, it is difficult to bring family members under the common denominator of internally displaced persons, defined by the Guiding Principles on Internal Displacement as "persons or groups of persons who have been forced or obliged to flee or to leave their homes or places of habitual residence, in particular as a result of or in order to avoid the effects of armed conflict, situations of generalized violence, violations of human rights or natural or human-made disasters, and who have not crossed an internationally recognized State border" (Guiding Principles on Internal Displacement, 1998). This definition fully applies to the detained families of Syrian and Iraqi fighters (since the camps are located on the territory of these countries), but does not apply to the migrants of other nationalities who have joined the Caliphate - it was never recognized as a State despite the fact that, for first time in the last 
100 years, it violated the territorial status quo established by the Sykes-Picot Agreement (Pre-State Israel: The Sykes-Picot Agreement, 1920)

Are foreign fighters prisoners of war, defined as "combatants who have fallen into the hands of the enemy, or specific non-combatants to whom the status of prisoner of war is granted by international humanitarian law" (Geneva Convention Relative to the Treatment of Prisoners of War (Third Geneva Convention), 1949)? The predominant position in international academic debate is that ISIS fighters do not cover these criteria. This does not mean, however, that they should be deprived of all human rights. By ethical reasons, we do not resort to the term unlawful combatants, used to refer to a person belonging to an armed group in the context where that person or group does not meet the conditions for combatant status. The term was coined by the administration of US President George W. Bush in the context of the "global war on terror" to designate individuals who they believed were neither combatants nor civilians but belonged to the third category of individuals who have been involved in hostilities and may be detained indefinitely without trial. We share the conviction that such an approach violates international humanitarian law and potentially diminishes the confidence in the international antiterrorist efforts.

Perhaps the most correct term to use to refer to the prisons' and camps' population is "detainees", meaning persons who have been subject to custodial deprivation of their liberty (Casebook, 2011). This is the term we are going to use further in the paper.

\section{Lessons Learned from History}

What currently happens in camps where families of foreign fighters are detained, has its historical precedents. One of them is Guantanamo. It was chosen deliberately to bring detainees out of U.S. court jurisdiction. This allowed the Bush administration, in response to a lawsuit by several detainees, to declare that U.S. courts have no jurisdiction over them, even if they are tortured or executed without trial or investigation. Detainees taken in Afghanistan and elsewhere far from the conflict area were interrogated, without access to the family or a lawyer, and without much hope of release. (Shackled detainees arrive in Guantanamo, 2002). Recidivism reached 21,2\% (HRF, 2017), which raised reasonable doubts about the efficiency of such an approach.

Another example is the Abu Ghraib prison where, between October and December 2003, several detainees became victims of blatant criminal abuses by staff members who were poorly trained and disoriented by contradictory instructions. When, on 24th of April 2004, photos became public, they provoked an international scandal. Five lessons have been learned from that sad experience: 1) any moral ambiguity about torture leads to more torture - nothing but the absolute, unequivocal condemnation of cruel interrogation methods can prevent it; 2) Torture cannot be cabined; 3) Torture is (mostly) ineffective; 4) The use of Torture is harmful to the United States (in a broader sense - to all 
who implement it); 5) The future debate about torture must consider its definition (Strauss, 2004).

Camp Bucca, located near the city of Basra in southern Iraq, not far from the border with Kuwait, is another example. Its history shows that, if vicious practices are changed, prisons can stop being Jihadi universities and instead become places of de-radicalization and disengagement. This became possible due to the following measures, introduced by the camp management: perfect maintenance of the facility; separation of extremists from the moderates; identification of motives - as a result it became clear that for most part the participation in the insurgency was a way to get extra money. Being aware who are the inmates, the camp command, in cooperation with the Ministry of Education, offered vocational training to help the detainees find job after being released: courses in Arabic and English language, Islam, Math, etc. Prisoners were also given the chance to improve their behavior and be released earlier. In a year, $40 \%$ of all camp population were released and recidivism fell below 1\% (Tasikas, 2009).

Based on these examples, the conclusion can be drawn that detention places contribute to radicalization when: 1) they are badly managed and do not provide proper living conditions; 2) they do not dispose of well trained personnel; 3) no separation between radicals and moderates is made; 4) motivation for joining the terrorist organization is not properly identified; 5) no educational opportunities and other activities which would facilitate the deradicalization and disengagement are offered by the camp's management; 6) violence, torture and other violations of human rights are committed; 7) the stay of the detainees is too long and they do not have the chance, through their conduct, to shorten it.

\section{Camps and Camps Population after the Military Defeat of ISIS}

The Islamic State has created one of the largest concentrations of migrants, estimated at 41,490 from about 80 countries around the world; $75 \%$ out of them are men, $13 \%$ - women and $12 \%$ - children. Of the 7366 repatriates, $79 \%$ are men, $4 \%$ - women and $17 \%$ - children (Cook,J. \& Vale,J., 2018). After the surrender of Baguz, the last stronghold of the Islamic State's resistance in Syria, the anti-terrorist coalition declared the military defeat of the Caliphate. More than 67,000 have fled the city area since early January, including 5,000 jihadists arrested during the surrender (Seldin, 2019). Civilians, mostly members of jihadist families, were transferred to camps in Iraq and Syria.

There is almost no research on the detainees in Iraq; the government is reluctant to provide information on this issue. Unlike Syria, Iraq continued lawsuits against foreigners on charges of ISIS membership or aiding a terrorist organization, as well as illegal entry into the territory. Such persecution affects men, women, and children over the age of nine; there is no information about their number. It is known that not only combatants are sentenced to death, but also civilian personnel (Houry, 2020). It seemed that Iraq was ready to transfer children and women to countries of origin, but since January 2018, changed its 
approach and began sending foreign females en masse to prosecutions. Many women were sentenced to 20 years in prison or to death penalty just because of being married an IS fighter or for having received a monthly allowance from IS after the death of their spouses (Abdul-Zahra, Q. and George, S., 2018). Cases are known of children condemned to five years in prison for ISIS membership and up to 15 years for involvement in violent activities (HRW, 2018).

After the liberation in the summer of 2017 of Raqqa, the surviving ISIS militants and their families fled to northwest Syria. Most of the males were detained and many are still in temporary prisons under the control of the Kurdish-led Syrian Democratic Forces. By the end of 2019, about 10,000 men (Debeuf, 2019) were being held in a separate network of pre-trial detention centers; about 2,000 are not Syrians or Iraqis. They are in seven prisons around Raqqa or further south in Syria. The families were placed in three camps: AlHol, Roj, and Ayn Issa. The largest, Al-Hol, has a population of about 70,000; 30,000 are Iraqis and 11,200 are foreigners of 54 different nationalities. Ninety percent are women and children; by the end of January 2021, their number amounted to 27,000 (Aljazeera, 2021). Roj is a refuge for about 1,700 people, 1,200 of whom are foreigners. Ayn Issa, $45 \mathrm{~km}$ north of Raqqa, had a population of 12,900, including 950 non-Syrians. In 2019, about 3,000 children there were unaccompanied (ICG, 2019).

$\mathrm{Al} \mathrm{Hol} \mathrm{covers} \mathrm{all} \mathrm{the} \mathrm{conditions} \mathrm{for} \mathrm{a} \mathrm{place} \mathrm{of} \mathrm{radicalization,} \mathrm{which} \mathrm{we}$ formulated in the previous section. From the point of view of living conditions, it is a humanitarian disaster. The camp was badly damaged by the Turkish invasion, which destroyed part of a primitive water supply and sanitation system; (MédecinsSansFrontières, 2020). As a result, less than $10 \%$ of health care needs are met today, and sexual violence against women and children is well documented (UNSecurityCouncil, 2021). The camp population at highest risk are the juveniles. The facility is not suitable for the long-term stay of children. The majority, about 23,000, do not go to school (Taylor, 2019) and develop high aggression as a result of the camp atmosphere (Bloom, 2015). Paradoxically, the seemingly positive fact of freedom of movement for children inside the camp, contributes to their radicalization, since they can be subjected to harmful radical influences. Probably some of the children were the subject of ISIS's educational program "The Lion Cubs of the Caliphate" (Bloom, 2015), whose goal was to socialize adolescents in total intolerance and violence (UN human rights office of the high commissioner. Syria: UN experts urge 57 States to repatriate women and children from squalid camps, 2021).

In the Joint Statement of January 21, 2021, on the deteriorating security in Al Hol, United Nations Resident Coordinator and Humanitarian Coordinator in Syria, Imran Riza, and Regional Humanitarian Coordinator for the Syrian Crisis, Muhannad Hadi (OCHA, 2021), Al Hol is called just a camp, not a refugee camp. This is not by chance. It, just as other places of detention, run by the Kurdish authorities, can be called a refugee camp only conditionally. It does not possess trained personnel. The small number of unskilled guards cannot control the huge population of the camp and the processes that take place within 
it. Female staff are under a constant threat. The reduction of the US military presence allowed ISIS ideology to spread unhindered outside and within these detention facilities with unclear status and hybrid nature, where women and children are deprived of any rights, basic services, or protection that UN camps offer.

Disorder, chaos, fear, insecurity, and indiscriminate violence have transformed Al Hol into a place of arbitrary actions of wives of the most determined supporters of the Islamic State. Half a year after the battle of Baghuz, IS-styled religious police was established in the ninth sector (AlKassab, 2021) of the camp called Hisba[h]. It enforces the established by the terrorist organization dress code, bans the smoking and brutally punishes women who share information with the staff and journalists. Burning tents, beating, killing, and dismembering the disobedient are among usual sanctions (Murdock, 2019). Female IS enforcers throw rocks and teach their children to throw rocks as a way of attacking; they have been trained and dispose of arms (Gardner, 2020).

In September 2019, Al Baghdadi called ISIS fighters to help reestablish the Caliphate inside the camps and to convert them in an epicenter of the Islamic State's resurgence. This gave reason to The Syrian Observatory for Human Rights to conclude that $\mathrm{Al} \mathrm{Hol} \mathrm{has} \mathrm{transformed} \mathrm{into} \mathrm{a} \mathrm{mini-state}$ ("Women's Hisbah" in al-Hol, between reality and media "propaganda" in light of the constant alert within the camp which is the home to tens of thousands of ISIS families, 2019), practically controlled by radicals (Rosen, 2021). These and other facts prove that the prolonged existence of such kind of detention facilities leads to further radicalization and an uncontrolled process of expansion of the influence of terrorist organizations. Practitioners and scholars widely agree that the best solution is the repatriation. In what follows, the experience of the four nations is presented.

\section{Albania}

Internal incentives

Number of migrants: Since the beginning of the conflict, around 100 nationals joined Daesh. In 2017, about 90 out of them were still with the Islamic State (Barret, 2017). Forty-five people returned, 26 allegedly died, 73 remain at the site of the conflict. (Balkan Daesh Fighters in Numbers, 2020). Before the Turkish operation "Spring of Peace" (2019), about 50 children were in Syrian camps; their number is difficult to determine, even though Turkey is exchanging information on this with the Albanian government (Balkan Daesh Fighters in Numbers, 2019). The difficulty in researching Albanian fighters has to do with the fact that ethnic Albanians from all the countries formed a kind of diaspora (Mejdini.F., 2019). As it can be seen, the number of Albanian nationals to be repatriated is not huge; the number of foreign fighters is even smaller.

Secular-oriented Muslim population: Compared to other societies in the Western Balkans, the Albanian one has peculiar characteristics. It is known 
for its high tolerance and secular character, as well as the prevalence of secular values over religious ones. A study on "Religious Tolerance in Albania" shows that although almost $37 \%$ of Albanians consider to be believers, less than $10 \%$ describe themselves as ones who believe in God and regularly practice all religious rituals (IDM, 2018). Moreover, all religious groups are perfectly integrated, so that none of them is a victim of isolation or marginalization. The general attitude of Albanians of all religions towards terrorism is extremely negative (IDM., 2015), which is why it was believed that the likelihood of terrorist attacks in the country was absent, although experts did not rule out the appearance of "lone wolves" (He tried to kill his father, the 28-year-old is arrested in Korça, 2016).

Government messages: At the beginning of 2019, the country's Interior Minister stressed that the goal for Albania is to return all children home in the next few months (Thorpe, 2019). The government first planned to repatriate dozens of citizens in August 2019. However, the process was suspended by certain changes in the geopolitical situation in Syria after the military operations of Turkey and the partial withdrawal of US troops in October 2019. It resumed under pressure from relatives and friends of migrants. Fifteen other Albanians were rescued from $\mathrm{Al} \mathrm{Hol}$ and then transferred to another camp, which is believed to be safer for them. (Euronews Albania secures footage filmed inside Al-Hol camp in Syria. Euronews Albania, 2020). Despite its modest scale, the repatriation operation was indicative of Albania's transition to an active approach to the repatriation and de-radicalization of its citizens. (Sahinkaya, L., Hussein, R. \& Bllaca, E., 2020)

Suitable legislation: Since 2014, Albania has taken active measures to counter and prevent the recruitment of its citizens as foreign fighters in conflicts abroad. Following amendments to the Criminal Code that criminalize acts of participation and recruitment in armed conflicts out of the country, the number of Albanian citizens participating in Syria and Iraq dropped to zero (Vurmo, 2018). At the same time, any repatriate will meet the court justice upon his or her return home.

Interinstitutional and intersectoral cooperation: The adoption in 2015 of the National Strategy and Action Plan against Violent Extremism, the campaign for raising public awareness, the engagement of Albanian Muslims, and numerous civil society initiatives to prevent violent extremism have all contributed to keeping the risks of violent extremism under control over the past two and a half years (Vurmo, 2018). Albania has developed a government rehabilitation program in which relatives, psychologists, teachers, and medical doctors participate.

Participation of civil society: Civil society got from the government and international donors strong financial support for de-radicalization projects. However, many of NGO do not possess the necessary institutional capacity and trained staff to implement them. Religious authorities have their special role in developing counter-narratives to violent extremism (Shehu, 2018). Finally, relatives of ISIS fighters whose families are still in Syria, exercise pressure on the government (Mejdini, 2020). 
External factors

Desire to prove oneself as a reliable international partner: Since the very beginning, Albania joined the anti-terrorist coalition and according to its possibilities, supported Kurdish forces with sending 22 million $7.62 \mathrm{~mm}$ rounds, 15,000 hand grenades and thousands of artillery shells only in 2015 (Andersson, J. \& Gaub, F., 2015). This support continued during the whole conflict.

Membership in international organizations: As a member state of NATO and a country applying for full membership in EU, Albania followed the course of both organizations.

International cooperation in repatriation operations: An operation was carried out to repatriate four children and one woman associated with Albanian militants. They were evacuated from the Al-Hol camp as a result of the mediation of the Syrian Arab Red Crescent; the Honorary Consul of Albania in Beirut Mark Ghraib also played an important role (Semini, 2020). The preparation took 12 months. According to the Special Anti-Corruption Prosecutor's Office of Albania, the woman will be investigated for participating in terrorist attacks during her seven years stay in Syria. Later, the Italian government, the Red Cross, and the Red Crescent worked actively with the Albanian side to repatriate an 11-year-old Albanian orphan boy, whose father lives in Italy.

\section{Bosnia and Herzegovina}

Internal incentives

Number of migrants: Bosniaks represent the largest number of foreign fighters from the Western Balkans; In 2015, BiH has the second largest number of foreign fighters per capita in Europe after Belgium (Strategy of Bosnia and Herzegovina for Preventing Terrorism, 2015). According to Bosnian intelligence, between 2012 and 2016, 241 adults and 80 children left Bosnia or the Bosnian diaspora for Syria and Iraq, where another 150 children were born. At least 88 people were killed or died. About 50 people returned to Bosnia on their own, including seven children (Sito-Sucic, 2019). By 2019, about 260 Bosnian citizens were sent in camps in Syria, including about 100 men and 160 women and children. There are no registered citizens of $\mathrm{BiH}$ who tried to travel to the conflict zone in 2019 and afterwards (Country Reports on Terrorism 2019: Bosnia and Herzegovina, 2019). For its population of 3765 000, the number of migrants is significant.

Secular-oriented Muslim population: The predominant opinion among scholars is that Bosnian Islam is peaceful and with secular orientation, despite the impact of Saudi Arabia, which became especially strong during and after the conflict in former Yugoslavia. A 2013 Pew Research Center study shows that Bosnians and Albanians are among the most liberal Muslims in the world (Akyol, 2019). The same are the conclusions of a report of Konrad Adenauer foundation, stating that Bosniaks' understanding of Islam is based on 
liberalism, desire for peace, reconciliation, and openness to the world" (Šuško, 2017).

Government messages: At the end of the conflict, the government made it clear that it was ready to accept ISIS fighters. The first step was taken in March 2019, when two people were repatriated with the help of the American side; one returned successfully (Balkan Daesh Fighters in Numbers, 2020). He is suspected of committing criminal acts in organizing a terrorist group, illegally forming, and joining foreign paramilitary or parapolice groups, and terrorism. Sentenced to 4 years in prison. There is no information about the second suspect (Bosnia To Bring Back, Put On Trial Two Nationals Suspected Of Joining IS In Syria March, 2010). Meanwhile, the government continued to negotiate to identify other Bosnian citizens in Syrian detention facilities. Bosnia has been preparing since October 2019 to return and prosecute nine suspected of fighting on the side of ISIS in Syria, but their repatriation has been delayed twice since Turkey invaded the northeast of the country (Former ISIS fighters under investigation after repatriation to Bosnia, 2019). On November 11, 2019, Bosnia's Security Minister Dragan Mektic announced that Sarajevo would accept all Bosnian citizens accused of involvement in Daesh but would bring legal action against them. (Lacroix, 2019). The repatriation operation took place on December 19, 2019. Twenty-five former ISIS fighters, women, and children, some of them orphans, returned to their homeland. Seven men were handed over to the state prosecutor, while 6 women and 12 children were taken to the reception center for further examination and medical assistance. The repatriation of the remaining Bosnian women and children has been postponed indefinitely due to the coronavirus pandemic (Bosnia Sentences Former IS Fighter To Four Years In Prison, 2019).

Suitable legislation: In 2014, Bosnia became the first in Europe to impose prison terms for its citizens who fought abroad. The militants, 46 people, who have returned from Syria and Iraq over the past few years, have been brought to justice and, in most cases, have been sentenced to prison (Former ISIS fighters under investigation after repatriation to Bosnia, 2019); the sentences, however, are significantly shorter than in EU countries (Balkan States Find Prosecuting Terrorism a Challenge, 2020). Although little progress has been made in the area of rehabilitation and de-radicalization, various civil society groups such as the Interfaith Council have made notable efforts to prevent and counter radicalization and terrorist recruitment (Country Reports on Terrorism 2019: Bosnia and Herzegovina, 2019).

Interinstitutional and intersectoral cooperation: The interinstitutional cooperation in $\mathrm{ByH}$ is especially difficult because of heavy and ineffective government mechanisms, established by the Dayton agreement, and contradictory legislation. To strengthen the process of re-integration, the government has established a multi-stakeholder coordinating body, including the Ministry of Security and the Ministry of Foreign Affairs (Lopes, M. \& Dukic, S., 2019). International institutions have sent two main recommendations to the country: create and develop de-radicalization programs in the penitentiary system, and support clerics who oppose extremism, engage 
them in the process, and produce messages to reach those who seek nonextremist interpretations of Islam (Lacroix, 2019).

Participation of civil society: International organizations assess positively the role of civil society in preventing and fighting violent radicalization but emphasize that they need to improve their institutional capacity and staff (OSCEPA, 2018).

External incentives

Desire to prove oneself as a reliable international partner: US authorities asked $\mathrm{BiH}$ in February 2019 to take back jihadists captured in the fight against Islamic State. BiH accepted, but not until the Council of Ministers sets up an operational body to investigate potential returnees, to determine their exact identity and connections in $\mathrm{BiH}$. After the creation of such a body, the Minister of Security, Mr. Mektic, said the country acts in fulfillment of its international obligations: " We are obliged to do so due to international conventions" (BiH returns its citizens who fought for Daesh, 2019).

Membership in international organizations. Although there is no explicit relation between repatriation and the aspiration of $\mathrm{BiH}$ to full membership in the EU, it could be supposed that EU has impacted the relevant decision. It is not by chance that precisely in the year of repatriation, EU appointed a new special representative for $\mathrm{BiH}$, who will also take over the role of head of the European Union Delegation in Sarajevo. Its mandate is based on the following objectives of EU policy in Bosnia and Herzegovina: continuous progress in the stabilization and association process; ensuring a stable, credible, peaceful, multiethnic and united state living in peaceful cooperation with its neighbors; guarantee that the country has irreversibly embarked on the path to EU membership (BjH EU appointed a special representative, 2019).

International cooperation in repatriation operations. There is little information about international cooperation in repatriating $\mathrm{BiH}$ nationals, except for the case of Ibro Kufurovic, who repatriated from Syria with US assistance (RadioFreeEurope, 2019). Although there is no reliable information about other cases, it could be supposed that USA and other states or international organizations have taken part in the process.

\section{Kosovo}

Internal incentives

Number of migrants: In terms of the number of fighters per capita, Kosovo ranks first in the world. Since 2012, more than 300-355 Kosovars have traveled to Syria and Iraq. In 2018, 413 remained in the place of the conflict. Compared to other countries in the Western Balkans, Kosovo ranks second in the number of women migrants (Tota, 2017). The total number of adult repatriates reached 250; 98 died in Syria, and dozens remained missing (Sahinkaya, E., Hussein,R. \& Bllaca, E., 2020). The percentage of women who returned was almost three times lower than that of men. This is probably due to the fact, that for women physical movement is more difficult, and that after the 
death of their husbands, female migrants are given as wives to other fighters. As for children, it is reported that about 76 were born in areas under the control of the Caliphate (Clingendael, 2020).

Secular-oriented Muslim population: After the independence, Kosovo Muslims became known for their pro-Western and secular views. This is due partly to the atheistic regime of J.B. Tito, who "repressed" all religions, not just Islam; partly to the immense respect towards the USA and personally to President Bill Clinton, whose administration did a lot for the liberation and independence of Kosovo. Today, Kosovo is a secular state that bans religious education in public schools and does not impose any restrictions on religious freedom other than a ban on radical Islam.

Government messages: In February 2019, the Prime Minister, Ramush Haradinaj sent a message that Kosovo is ready to repatriate all those who fought for the Islamic State in Syria and Iraq (Kosovo ready to repatriate citizens who fought for IS - PM, 2017). The administration of this small country has repeatedly stated that they consider women and children "innocent victims" lured by their husbands and fathers into the conflict zone. It was said that if returned, they would not be convicted, although this was later changed. The government carried out a repatriation operation on April 20, 2019. 110 people were repatriated, including four militants, 32 women, and 74 children, including nine unaccompanied; 30 Kosovar fighters, 49 women, and 8 children are still in the conflict zones. Most of them are in camps in northeastern Syria (Kosovo repatriates over 100 fighters and families from Syria, 2019). Women and children were returned to their families and communities after an initial 72hour waiting period for physical and mental health checks (Country Reports on Terrorism 2019: Kosovo, 2019). The court ruled to place the women under house arrest based on credible suspicion that they have fomented or participated in foreign conflicts. Upon their return to Albania, the men were arrested and soon brought to trial.

Suitable legislation: Several factors influenced the government decision to repatriate its nationals from Syria and Iraq: changes in legislation (2015), existence of a strategy and plan for countering violent extremism (20152020); existence of a special body - the Department for the Prevention and Reintegration of Radicalized; appointment of a national coordinator and creation of specific projects aimed at de-radicalization of repatriates. At the same time, Kosovo has certain experience of litigating Islamist extremists. Since 2014, more than 150 IS supporters have been arrested and more than 80 sentenced to punishment. Based on seven years of experience, it can be argued that when released, they pose a "controlled threat" (Hein, M., Felden, E., \& Cani, B., 2019) - "a small number of repatriates (5 people) is still very radical" (Sahinkaya, E., Hussein,R. \& Bllaca, E., 2020). In 2015, Kosovo passed a law according to which participation in foreign conflicts is punishable by imprisonment for up to 15 years.

Interinstitutional and intersectoral cooperation: The Kosovo Strategy and Action Plan to Fight Violent Extremism (2015-2020), with its comprehensive character, provides a five-year roadmap for countering the 
threat of terrorism, highlighting the critical role of local stakeholders and civil society. An inter-agency working group is developing a revised strategy to combat terrorist radicalization and recruitment to focus on the re-integration of returnees (Sahinkaya, E., Hussein,R. \& Bllaca, E., 2020). The government established the Prevention and Reintegration Unit, an inter-ministerial agency dedicated to supporting repatriated women and children, to coordinate, collaborate, communicate, monitor, and evaluate the re-integration process; its task is to prevent the radicalization of young people and other groups, as well as to assist in the re-integration of those who have returned from conflict zones. Its approach is based on community efforts at the local level, combined with broader national efforts.

Participation of civil society: A unique project to rehabilitate ISIS repatriated families has begun in Kosovo. Within its framework, women and children participate in special training sessions and receive vouchers for food and clothing. Those in prison also take part in de-radicalization programs, caried out with the participation of psychiatrists, family therapists, imams, and female preachers called Mualim. Mualim are a kind of a bridge between women and society; they visit female returnees and help to understand the true value of Islam for them and help them re-integrate. At the same time, they are working with local communities to accept these women and children, since Kosovar society tends to stigmatize migrants to/from ISIS. For this reason, part of the rehabilitation project includes regular meetings with neighbors and villagers in their communities. Since returnees suffer from post-traumatic stress disorder and depression, the mental health program designed for them includes home visits, individual and family sessions, outdoor activities, and a process of reintegration into society through school and training courses. Twenty psychologists visit the homes of repatriates and communicate with their neighbors, while for treatment sessions, the repatriates are taken out of the house (Hein, M., Felden, E., \& Cani, B., 2019). As a result, all children around the age of six were able to start a successful new school year in September.

\section{External incentives}

Desire to prove oneself as a reliable international partner: Kosovo is a member of the Global Coalition to Defeat Daesh. It declared independence only in 2008 and is still lacking full recognition from the international community. Currently, it is in a process of difficult negotiations with Serbia, which continues the question over its legitimacy. Seeking to contribute to the image of Kosovo as a reliable international partner, Kosovan Justice Minister Abelard Tahiri said: "As Kosovo, we cannot allow that our citizens be a threat to the West and to our allies." (Bytyci, 2019).

Membership in international organizations: Last September, the dialogue between Serbia and Kosovo was broken. More than once, EU sent to both parties the message that they must resume talks with each other to make progress on EU membership. It is logical to assume that Kosovo, which needs very much international support, would take steps - as for example, repatriation - which would be positively assessed by the UN and EU. The U.S. Embassy in 
Pristina issued a statement in which it is said: "With this repatriation, Kosovo has set an important example for all members of the Global Coalition to Defeat ISIS and the international community to follow. We applaud their compassion in accepting the return of this large number of civilians" (Bytyci, 2019).

International cooperation in repatriation operations: The operation was carried out with the help of the United States, which, on behalf of the Kosovo side, negotiated with the Syrian Democratic Forces the details of the repatriation operation (Hein, M., Felden, E., \& Cani, B., 2019).

\section{Republic of North Macedonia}

Internal incentives

Number of migrants: According to a report of the Extremism Research Forum (2017), at the beginning of 2018, the number of Daesh fighters from North Macedonia reached 140 men and 14 women (Bećirević, E., Halilović, M., \& Azinović, V., 2017). According to other sources, at least 156 citizens of North Macedonia joined terrorist groups in Syria and Iraq. Thirty-five people died, about 38 remained on the conflict field, and 83 people returned to their homeland (Country Report on Terrorism 2018 - Chapter 1 - North Macedonia, 2018). North Macedonia has the second-largest return of fighters.

Secular-oriented Muslim population: Islam in the Republic of Northern Macedonia is rather moderate and secular despite of the penetration of some radical trends in it (Marusich, 2008). As early as the beginning of 2014, the head of the Islamic Religious Community in Macedonia warned Muslims in the country not to get involved in the sectarian conflict raging in Syria (Marusic, 2014). This position has been kept till the end of the conflict.

Government messages: North Macedonia ranks second in militant returns. Thirteen convicts are currently serving sentences of imprisonment. Only 3 of them are not ISIS returnees, meaning they were not on the front lines in Syria and Iraq, but were convicted of recruiting, funding, and ensuring the departure of volunteer fighters. In addition, one more person is in jail (Vanchoski A, 2020). In August 2018, North Macedonia repatriated and detained seven citizens from the custody of the Syrian Democratic Forces for investigation, becoming one of the first countries to do so successfully (Country Report on Terrorism 2018 - Chapter 1 - North Macedonia, 2018).

Suitable legislation: In North Macedonian criminal law, terrorism is punishable by a prison sentence of ten years to life imprisonment. In 2014, an article was added to the Criminal Code that deals with hostilities abroad. It provides a minimum sentence of four years imprisonment for any citizen who takes part in an unauthorized foreign military, police, paramilitary, or parapolice group (Rovcanin, R., Mejdini, F., Kajosevic, S., Bami,X., \& Marusic S., 2020). Equally important were the cross-financing measures for terrorist organizations. In 2019, the government passed the necessary by-laws to the Restrictive Measures Act, including the Guidelines for the Application of Financial Restrictive Measures against Terrorism and the Proliferation of 
Weapons of Mass Destruction; the decision to create a coordinating body to control the implementation of restrictive measures; and a set of rules for maintaining a list of designated individuals against whom financial measures have been taken concerning terrorism (Rovcanin, R., Mejdini, F., Kajosevic, S., Bami,X., \& Marusic S., 2020).

Interinstitutional and intersectoral cooperation: The repatriation operation became possible thanks to the creation of an anti-terrorist structure deployed in the country. To prevent radicalization, the government of North Macedonia presented two strategies in March 2018 - the Prevention of Violent Extremism and the updated Counter-Terrorism Strategy (Balkan Daesh Fighters in Numbers, 2019), which became fundamental to the policy in the fight against terrorism and violence radicalization. The Parliament of North Macedonia adopted a comprehensive rehabilitation and re-integration plan as part of an effort to return home some 40 citizens (mostly women and children). With political, financial, and technical support from the international community, the plan also extends to terrorists who are soon to be released from prison. (Selimi, K., \& Stojkovski, F., 2020). This plan meets several challenges: the need for staff training, lack of awareness of civil servants outside the security sector about the problems of repatriates, inter-institutional cooperation, etc. (Rosand, E., Ellis, H..,\& Weine S., 2020). The changes that Macedonia introduced for the repatriation helped the country to better prepare for the deradicalization of many convicted terrorists, who were sentenced to short terms in 2012 and afterwards, and will soon be released, as well as of the 83 of the 156 North Macedonian citizens who went to Iraq and Syria have already returned home. According to security officials the likelihood of recidivism among them exists, but it can be controlled (Rosand, E., Ellis, H..,\& Weine S., 2020).

Participation of civil society: In the rehabilitation and reintegration plan, the participation of civil society is especially emphasized (Selimi, K., \& Stojkovski, F., 2020). Another expression of the civil society engagement is the activity of the relatives of the migrants, who insist for their repatriation and are ready to cooperate in the de-radicalization process.

External incentives

Desire to prove oneself as a reliable international partner: The readiness of the Republic of North Macedonia was noticed. The repatriation operation was highlighted by the US Department of Defense as a positive step that could serve as an example for other countries (Munos, 2018).

Membership in international organizations: As a recently accepted member of NATO, and a candidate for EU membership, the Republic of North Macedonia feels the conditionality of these organizations - their power to impact decisions and acts of the national institutions.

International cooperation in repatriation operations: Macedonian government took advantage of the willingness of international partners and Kurdish forces to help carry out such an operation. Seven militants were 
previously in the custody of the Democratic Forces of Syria (Country Report on Terrorism 2018 - Chapter 1 - North Macedonia, 2018). In collaboration with partners from the Global Coalition Against Terrorism and the Syrian Democratic Forces, they were arrested and handed over to Macedonian law enforcement. This was highlighted by the US Department of Defense as a positive step that could serve as an example for other countries (Munos, 2018).

\section{Who in the Western Balkans repatriates ISIS fighters?}

As it can be seen, all the States have secular-oriented Muslim populations and suitable legislation that assures that all who return will meet justice in the legal courts. All governments have sent clear messages that were listened to by the migrants and correctly decoded by them. Albania, Kosovo and Northern Macedonia had effective interinstitutional and intersectoral cooperation. Due to its complex administrative structure, $\mathrm{BiH}$ needed more time to consolidate such a cooperation. It rejected starting the repatriation before creation of a coordination agency, which delayed the repatriation. A conclusion could be drawn that the internal readiness and existence of a social anti-terrorist infrastructure influenced positively the decision-making process.

The impact of external variables also deserves a deep analysis. We identified interdependence between the repatriation operations and the strength and the urgency of the need for international support. The first in undertaking repatriation was the Republic of North Macedonia (08/2018). It repatriated relatively small number of people - 7 , but all of them were male terrorist fighters; around 83 returned on their own. Macedonia was a new State, which at that moment needed a lot of international support - first, for the change of its name (February 2019), because the veto of Greece was the most serious barrier on the way to the EU, and second, for the membership in NATO to which it integrated in March of 2020. Kosovo was the second (04/2019). It repatriated 110 persons, but only 4 of them were terrorist fighters. Around 250 persons have already returned on their own. Kosovo is a new state, approximately 90 countries do not recognize its sovereignty, 5 out of them - from the EU. Moreover, it is in long and heavy negotiations with Serbia. Kosovo needed international support; it chose to return great number of women and children, which contributed to its positive image, what was met with approval by its international partners. The small number of men returned can be explained by the great number of fighters who got home by themselves - eventually, a great bulk of militants can challenge and even seriously damage national security. $\mathrm{BiH}(12 / 2019)$ repatriated 25 persons; 7 of them were male terrorist fighters. The number of people who returned on their own was relatively low -50 . At that moment BiH didn't need urgently international support - it was still far from NATO and EU membership. This could partly explain why the country was not in a hurry to take back its militants; another explanation has to do with the complex administrative structure and political system, which require time to produce any viable decision. Albania was the last (10/2020). It did not repatriate any males, only women and children. The number of the returnees 
was 45. Albania is an old state, member of the international community since many years. In 2019, when the UN and the USA called for repatriation, Albania was already a member of NATO and still far from EU membership. It didn't need urgently international support.

The variable "membership in international organizations" has also some impact. Countries for which membership in NATO or the EU was an immediate perspective, were more prone to carry out repatriation. Countries that were already members, or the membership was a long-term perspective, did not seem to be impacted by this factor. UN, OSCE and the Council of Europe are the international organizations that called for repatriation. USA also urged European countries to take back their nationals and did it include in the meetings of NATO (for instance, the NATO Leaders Meeting in London in 2019), even though the Alliance never included such a call in its official policy. EU and NATO never used the strong leverage of conditionality to impact decisions in regard to repatriation, except, probably implicit reaction of the European Union which, after the repatriation effectuated by $\mathrm{BiH}$, appointed a new special representative for the country, who also took over the role of head of the European Union Delegation in Sarajevo and had to monitor the continuous progress in the stabilization and association process. However, this could be only a coincidence; it is possible that both events are not related by any causal tie.

Finally, the analysis and assessment of the operations of repatriation shows that these are complex diplomatic, humanitarian and security operations that cannot be successful without the international coordination among governments, humanitarian organizations, key stakeholders in the stage of the conflict, and anti-terrorist coalitions.

\section{Conclusions}

Four small states of the Northern Balkans, which do not possess the resources of economically powerful and politically stable European countries, have repatriated their nationals from Iraq and Syria. Despite the lack of experience, heretofore they have been successful in the efforts towards deradicalization and disengagement of foreign fighters and their families. Albania, BiH, Kosovo and Republic of North Macedonia have been pointed out as positive example by many international, humanitarian, and other organizations. Only time will show whether these are sustainable outputs or just intermediate results that are not indicative of the positive advance of the process. Our research shows that when there is a suitable constellation of internal and external drives, this generates enough political will as to carry such a risky act as repatriation of terrorist fighters and their families. The fact that NATO and the EU never made of repatriation their policy and, thus, never used conditionality to motivate respective countries, demonstrates that again national interests of the member states have proven to be stronger than the collective ones. 


\section{Bibliography}

"Women's Hisbah" in al-Hol, between reality and media "propaganda" in light of the constant alert within the camp which is the home to tens of thousands of ISIS families. (2019, October 2). Retrieved June 9, 2021, from The Syrian Observatory of Human Rights: https://www.syriahr.com/en/142510/

Abdul-Zahra, Q. and George, S. (2018, March 21). Iraq Holding More than 19,000 Because of IS,. Associated Press. Retrieved June 13, 2021, from https://www.apnews

Akyol, R. (2019, January 13). Want to Cultivate a Liberal European Islam? Look to Bosnia. The Atlantic. Retrieved June 10, 2021, from https://www.theatlantic.com/international/archive/2019/01/bosniaoffers-model-liberal-european-islam/579529/

Aljazeera. (2021, January 10). UN urges countries to repatriate 27,000 children from Syria camp. Retrieved May 7, 2021, from https://www.aljazeera.com/news/2021/1/30/un-urges-countries-torepatriate-27000-children-from-syria-camp

Al-Kassab, H. (2021, February 21). Syria Direct. Retrieved June 8, 2021, from Al-Hol emirate': How ISIS turns the prison-like camp into a stronghold, Retrieved June 10, 2021, from https://syriadirect.org/alhol-emirate-how-isis-turns-the-prison-like-camp-into-a-stronghold-2/

Andersson, J. \& Gaub, F. (2015, July). Adding fuel to the fire? Arming the Kurds. ISSU Alert(37), 2. Retrieved June 10, 2021, from https://www.iss.europa.eu/sites/default/files/EUISSFiles/Alert_37_Ku rds.pdf

Arraf, J. (2019, December 8). Visiting Imprisoned ISIS Fighters. NPR. Retrieved June 8 , 2021, from https://www.npr.org/2019/12/08/786039731/visiting-imprisoned-isisfighters

Balkan Daesh Fighters in Numbers. (2019, December 18). Retrieved April 7, 2021, from https://politicstoday.org/balkan-daesh-fighters-innumbers/

Balkan Daesh Fighters in Numbers. (2020, December 19). Retrieved April 7 , 2021,from Politics Today: https://politicstoday.org/balkan-daeshfighters-in-numbers/

Balkan States Find Prosecuting Terrorism a Challenge. (2020, August 21). Retrieved March 17, 2021, from Regional Cooperation Council: 
https://www.rcc.int/swp/news/290/analysis-balkan-states-findprosecuting-terrorism-a-challenge

Barret, R. (2017). Beyond The Caliphate: Foreign Fighters and the Threat of Returnees. The Soufan Center. Retrieved April 7, 2021, from https://thesoufancenter.org/wp-content/uploads/2017/11/Beyond-theCaliphate-Foreign-Fighters-and-the-Threat-of-Returnees-TSCReport-October-2017-v3.pdf

Bećirević, E., Halilović, M., \& Azinović, V. (2017). Literature Review Radicalisation And Violent Extremism In The Western Balkans. Retrieved March 29, 2021, from Extremist Research Forum: https://kosovo.britishcouncil.org/en/programmes/educationsociety/western-balkans-extremism-research-forum

Berger, M. (2019, October 14). Here's what we know about the ISIS prisons controlled by the Syrian Kurds. The Washington Post. Retrieved June 8, 2021, from https://www.washingtonpost.com/world/2019/10/12/inside-isisprisons-controlled-by-syrian-kurds/

$\mathrm{BiH}$ returns its citizens who fought for Daesh. (2019, November 11). News.bg. Retrieved 10 June, 2021, from https://news.bg/int-politics/bosna-sipribira-grazhdanite-bili-se-za-daesh-v-siriya.html

BjH EU appointed a special representative. (2019, August 11). EC. Retrieved June 10, 2021, from https://www.consilium.europa.eu/bg/press/pressreleases/2019/08/08/bosnia-and-herzegovina-eu-appoints-newspecial-representative/

Bloom, M. (2015, July 21). Cubs of the Caliphate: The Children of ISIS. Foreign Affairs. Retrieved April 3, 2021, from https://www.foreignaffairs.com/articles/2015-07-21/cubs-caliphate

Bosnia Sentences Former IS Fighter To Four Years In Prison. (2019, December 27). Retrieved from Radio Free Europe: https://www.rferl.org/a/bosnia-sentences-former-is-fighter-to-fouryears-in-prison/30347644.html

Bosnia To Bring Back, Put On Trial Two Nationals Suspected Of Joining IS In Syria March. (2010, March 9). Retrieved June 6, 2021, from Radio Liberty: https://www.rferl.org/a/bosnia-herzegovina-bring-backsuspected-islamic-state-fighters-syria/29812474.html

Bytyci, F. (2019, April 20). Kosovo brings back fighters, families of jihadists from Syria. REUTERS. Retrieved June 10, 2021, from https://www.reuters.com/article/us-kosovo-syria-idUSKCN1RW003 
Casebook. (2011). ICRC. Retrieved June 6, 2021, from https://casebook.icrc.org/glossary/detainees

Clingendael. (2020). What EU Member States can learn from Kosovo's experience in repatriating former foreign fighters and their families. Retrieved June 6, 2021, from https://www.clingendael.org/sites/default/files/2020-

06/Policy_Brief_Kosovo_experience_repatriating_former_foreign_fig hters_May_2020.pdf

Constitution of the International Refugee Organization. (1946, December 15). Treaty Series, 18, 1-15. United Nations. Retrieved June 4, 2021, from Treaty Series: https://www.refworld.org/docid/3ae6b37810.html

Cook,J. \& Vale,J. (2018). From Daesh to 'Diaspora':Tracing the Women and Minors of Islamic State. Retrieved June 13, 2021, from https://icsr.info/wp-content/uploads/2018/07/ICSR-Report-From-

Daesh-to-\%E2\%80\%98Diaspora\%E2\%80\%99-Tracing-the-Womenand-Minors-of-Islamic-State.pdf

Country Report on Terrorism 2018 - Chapter 1 - North Macedonia. (2018). US Department ofState. Retrieved June 9, 2021, from https://www.ecoi.net/en/document/2019326.html

Country Reports on Terrorism 2019: Bosnia and Herzegovina. (2019). US Department of State. Retrieved June 5, 2021, from https://www.state.gov/reports/country-reports-on-terrorism2019/bosnia-and-herzegovina/

Country Reports on Terrorism 2019: Kosovo. (2019).USA Department of State. Retrieved May 15, 2021, from USA Department of State: https://www.state.gov/reports/country-reports-on-terrorism2019/kosovo/

Debeuf, K. (2019, October 10). Turkish attack on Syria might revive Isis. Retrieved May 17, 2021,from EUObserver: https://euobserver.com/foreign/146219

Donnelly, M., Sanderson, T. \& Fellman, Z. (2017). Foreign Fighters. Center for Strategic and International. Retrieved May 17, 2021

Dronzina, T. \& Medikhanova, A. (2021). Diplomatic And Humanitarian Operations For Repatriation Of Migrants Of The Islamic State. Aktau: Yessenov University Press.

Euronews Albania secures footage filmed inside Al-Hol camp in Syria. Euronews Albania (2020). [Motion Picture]. Retrieved June 1, 2021, 
from https://euronews.al/en/daily-news/2020/10/27/exclusive-videoeuronews-albania-secures-footage-from-inside-al-hol-camp-in-syria

Former ISIS fighters under investigation after repatriation to Bosnia. (2019, December 20). Retrieved April 3, 2021, from The National : https://www.thenationalnews.com/world/europe/former-isis-fightersunder-investigation-after-repatriation-to-bosnia-1.953853

Geneva Convention (IV) relative to the Protection of Civilian Persons in Times of War. (1949, August 12). 184. UNHR. Retrieved June 6, 2021, from https://www.un.org/en/genocideprevention/documents/atrocitycrimes/Doc.33_GC-IV-EN.pdf

Geneva Convention Relative to the Treatment of Prisoners of War (Third Geneva Convention). (1949, August 12). Retrieved June 12, 2021, from https://www.un.org/en/genocideprevention/documents/atrocitycrimes/Doc.32_GC-III-EN.pdf

Guiding Principles on Internal Displacement. (1998, February 11). Retrieved June 6 , 2021, from https://www.icrc.org/en/doc/assets/files/publications/icrc-0021124.pdf

He tried to kill his father, the 28-year-old is arrested in Korça. (2016, June 12). tv.channel. Retrieved June 6, 2021, from http://topchannel.tv/2016/12/06/tentoi-te-vriste-babane-e-tij-arrestohet-28vjecari-ne-korce/

Hein, M., Felden,E., \& Cani, B. (2019, February 10). Islamic State' returnees in Kosovo guided back into society. Retrieved June 12, 2021, from DW: https://www.dw.com/en/islamic-state-returnees-in-kosovoguided-back-into-society/a-50668479

Hénin, N. (2021, May 11). We Must Try ISIS' Terrorists-or Risk Creating New Ones. Retrieved June 8, 2021, from We Must Try ISIS' Terrorists - or Risk Creating New Ones

Houry, N. (2020). The "Unreturned": Dealing with the Foreign Fighters and Their Families. In S. \&. Pektas, Militant Jihadism. Today and Tomorrow (pp. 60-81).

HRF. (2017, February 22). Guantanamo Recidivism and the Myth That Keeps on Giving. Retrieved June 13, 2921, from https://www.humanrightsfirst.org/blog/guantanamo-recidivism-andmyth-keeps-giving

HRW. (2018, JUne 18). Iraq: Change Approach to Foreign Women, Children. HRW. Retrieved June 6, 2021, from https://www.hrw.org/ 
ICG. (2019). Women and Children First: Repatriating - Middle East Report $\mathrm{N}^{\circ}$ 208. Retrieved from https://www.crisisgroup.org/middle-eastnorth-africa/eastern-mediterranean/syria/208-women-and-childrenfirst-repatriating-westerners-affiliated-isis

IDM. (2018). Religious tolerance in Albania. Retrieved April 6, 2021, from https://idmalbania.org/wp-content/uploads/2018/04/Religioustolerance-in-albania.pdf

IDM. (2015). Religious radicalism and violent extremism in Albania. Retrieved April 6, 2021, from http://idmalbania.org/wpcontent/uploads/2015/07/Religious-Radicalism-Albania-web-final.pdf

Jenks, C. (2016). Reimagining the Wheel: Detention and Release of Non- S tate Actors under the Geneva Conventions. In G. \&. Rose, Detention of Non-State Actors Engaged in Hostilities (p. 97). Brill. doi:https://doi.org/10.1163/9789004310643_006

Kosovo ready to repatriate citizens who fought for IS - PM. (2017, December 1). Retrieved May 3, 2021, from BBC Monitoring Europe: https://advance.lexis.com/api/document?collection=news\&id=urn:con tentItem:5R31-GP01-JC8S-C4C3-00000-00\&context=1516831

Kosovo repatriates over 100 fighters and families from Syria. (2019, April 20). Retrieved May 23, 2021, from The National: https://www.thenationalnews.com/world/mena/kosovo-repatriatesover-100-fighters-and-families-from-syria-1.851553

Lacroix, R. (2019, November 22). Bosnia Needs a Smooth Repatriation Process to Benefit Counterterror Efforts. Retrieved March 17, 2021, from Risetopeace: https://www.risetopeace.org/2019/11/22/bosniarepatriation/rlacroix/

Lopes, M \& Dukic, s. (2019, July 19). Repatriation of Foreign Terrorist Fighters: Cases for the West. Retrieved from European eye on radicalization: https://eeradicalization.com/repatriation-of-foreignterrorist-fighters-cases-for-the-west/

Marusic, M. (2014, January 15). Top Macedonian Muslim Warns Against Joining Syrian War. BalkanInsight. Retrieved June 11, 2021, from https://translate.google.bg/?hl=en\&tab=mT\&sl=bg\&tl=en\&text=\%D0 $\%$ BE\%D1\%89\%D0\%B5\%20\%D0\%B2\%20\%D0\%BD\%D0\%B0\%D1 $\% 87 \% \mathrm{D} 0 \% \mathrm{~B} 0 \% \mathrm{D} 0 \% \mathrm{BB} \% \mathrm{D} 0 \% \mathrm{BE} \% \mathrm{D} 1 \% 82 \% \mathrm{D} 0 \% \mathrm{BE} \% 20 \% \mathrm{D} 0 \% \mathrm{~B}$ D\%D0\%B0\%202014\%20\%D0\%B3\%D0\%BE\%D0\%B4\%D0\%B8\% $\mathrm{D} 0 \% \mathrm{BD} \% \mathrm{D} 0 \% \mathrm{~B} 0 \& \mathrm{pp}=$ translate 
Marusich, I. (2008). The Islam inMacedonia. Geopolotica(6). Retrieved June 10, 2021, from https://geopolitica.eu/spisanie-geopolitika/992008/broi6-2008/777-islyamat-v-makedoniya

MédecinsSansFrontières. (2020, August 27). In Al-Hol camp, almost no healthcare is available and the consequences are devastating. Retrieved June 17, 2021,from Reliefweb: https://reliefweb.int/report/syrian-arab-republic/al-hol-camp-almostno-healthcare-available-and-consequences-are

Mejdini, F. (2020, September 15). Families of Albanian Children in Syrian Camps Rally for Their Retur. Balkaninsight. Retrieved June 10, 2021, from https://balkaninsight.com/2020/09/15/albanian-families-ofchildren-in-syria-protest-for-their-return/

Mejdini.F. (2019, April 18). Families of Albanian ISIS Fighters Face Long Road Home. Retrieved April 7, 2021, from https://balkaninsight.com/2019/04/18/families-of-albanian-isisfighters-face-long-road-home/

Munos, C. (2018, August 7). Pentagon praises Macedonia for repatriation of ISIS foreign fighters. Retrieved June 7, 2021, from The Washington Times:

https://www.washingtontimes.com/news/2018/aug/7/pentagonpraises-macedonia-repatriation-isis-forei/

Murdock, H. (2019, October 17). Syria Camp Housing Hardcore IS Families Spiraling 'Out of Control'. Retrieved June 8, 2021, from VOA: https://www.voanews.com/middle-east/syria-camp-housing-hardcorefamilies-spiraling-out-control

OCHA. (2021, January 21). Joint Statement on the deteriorating security in Al Hol from January 21, 2021, United Nations Resident Coordinator and Humanitarian Coordinator in Syria Imran Riza, and Regional Humanitarian Coordinator for the Syrian Crisis Muhannad Hadi. Damascusand Amman. Retrieved June 5, 2021, from https://www.humanitarianresponse.info/sites/www.humanitarianrespo nse.info/files/documents/files/21_january_joint_statement_on_al_hol _-_final.pdf

OSCE. (2018). Guidelines for Addressing the Threats and Challenges of "Foreign Terrorist Fighters" within a Human Rights Framework. OSCE. Retrieved June 4, 2021, from https://www.osce.org/odihr/393503

OSCEPA. (2018). Note to the fileofficial visit to bosnia and herzegovina. Ad hoc committee on countering terrorism. Retrieved June 10, 2021, from 
https://www.oscepa.org/en/documents/all-documents/ad-hoccommittee-on-migration/3755-note-to-the-file-visit-of-the-osce-paad-hoc-committee-on-countering-terrorism-to-bosnia-andherzegovina-5-8-june-2018/file

Pre-State Israel: The Sykes-Picot Agreement. (1920, April). Jewish Virtual Library. Retrieved June 6, 2021, from https://www.jewishvirtuallibrary.org/the-sykes-picot-agreement-1916

Protocol additional to the Geneva conventions of 12 august 1949, and relating to the protection of victims of international armed conflicts. (1977, June 8). Protocol I, Of 8 June 1977. Retrieved June 6, 2021 from https://www.ohchr.org/EN/ProfessionalInterest/Pages/ProtocolI.aspx

RadioFreeEurope. (2019, December 27). Bosnia Sentences Former IS Fighter To Four Years In Prison. Retrieved June 6, 2021, from https://www.rferl.org/a/bosnia-sentences-former-is-fighter-to-fouryears-in-prison/30347644.html

Raychev, Y. (2020, June). Perations for repatriation of citizens of Kazakhstan, Tajikistan and Uzbekistan that joined ISIS. Diplomacy, 47-58. Retrieved June 12, 2021, from https://bdi.bg/data/DJ/DJ_24.pdf

Refugees and Displaced Persons 62 (I). (1946, 15 December). Retrieved June 4, 2021, from UN General Assembly: https://www.unhcr.org/excom/bgares/3ae69ef14/refugees-displacedpersons.html

Rosand, E., Ellis, H.,\& Weine S. (2020, September 14). Repatriating ISIS Family Members: A North Macedonia Model? Retrieved June 3, 2021, from Just Security: Ellis and Stevan Weine. Repatriating ISIS Family Members: A North Macedonia Model?

Rosen, K. (2021, April 8). FIKRA FORUM. Retrieved June 13, 2021, from https://www.washingtoninstitute.org/policy-analysis/addressinghumanitarian-and-security-crises-al-hawl

Rovcanin, R, Mejdini, F, Kajosevic, S., Bami,X, \& Marusic S. (2020, July 6). Balkan States Find Prosecuting Terrorism a Challenge. Balkan investigative reporting network. Retrieved June 13, 2021, from balkaninsight.com: https://balkaninsight.com/2020/07/06/balkanstates-find-prosecuting-terrorism-a-challenge/

Sahinkaya E Hussein,R \& Bllaca, E. (2020, Jamuary 15). Why is Kosovo Taking Home Islamic State Members? Retrieved May 23, 2021, from VOA: https://www.voanews.com/extremism-watch/why-kosovotaking-home-islamic-state-members 
Sahinkaya, L., Hussein, R \& Bllaca, E. (2020, April 17). Albanian IS Repatriation From Syria Will Be Long Journey, Experts Say. Retrieved June 10, 2021, from VOA: https://www.voanews.com/extremismwatch/albanian-repatriation-syria-will-be-long-journey-experts-say

Seldin, J. (2019, April 2). Islamic State Still Showing Signs of Life in Syria's Baghuz. Retrieved June 8, 2021, from VOA: https://www.voanews.com/middle-east/islamic-state-still-showingsigns-life-syrias-baghuz

Selimi, K., \& Stojkovski, F. (2020). Assessment of macedonia's efforts in counteringviolent extremism, view from civil society. Retrieved June 12, 2021, from Macedonia Analytica: https://www.analyticamk.org/images/Files/extremism-en-updatedFINAL-web_ceb98.pdf

Semini, L. (2020, October 26). Albania repatriating 5 family members of fighters in Syria. Retrieved June 8, 2021, from AP: https://apnews.com/article/albania-iraq-middle-east-lebanon-tiranad0bb9fb7cfcb72f472beca172e9d0bce

Shackled detainees arrive in Guantanamo. (2002, January 11). CNN. Retrieved June 13, 2021, from https://edition.cnn.com/2002/WORLD/asiapcf/central/01/11/ret.detain ee.transfer/index.html

Shehu, R. (2018). Reconsidering the role of civil society and religious authorities in building community resilience in Albania. Institute for Democrcy and Mediation, December. Institute for Democrcy and Mediation. Retrieved June 10, 2021, from Institute for Democrcy and Mediation

Sito-Sucic, D. (2019, March 8). Bosnian women struggle to return female relatives, children from Syria. Reuters. Retrieved 6 2021June, from https://www.reuters.com/article/us-mideast-crisis-bosnia-syriaidUSKCN1QP19P

Strategy of Bosnia and Herzegovina for Preventing Terrorism. (2015).U.S. Department of State. Retrieved June 1, 2021, from https://www.refworld.org/docid/57518dd615.html

Strauss, M. (2004). The Lessons of Abu Ghraib. OHIO STATE LAW JOURNAL, 1270-1310. Retrieved June 13, 2021, from https://core.ac.uk/download/pdf/159609291.pdf

Šuško, D. (2017). A Model for Europe? Konrad Adenauer Foundation. Retrieved June 10, 2021, from 
https://www.kas.de/en/web/auslandsinformationen/artikel/detail//content/ein-modell-fuer-europa-

Tasikas, V. (2009, September-October). The battlefields inside the wire. Detention operations under major general Doiglas Stone. Military Review, 64-71. Retrieved June 8, 2021, from https://www.armyupress.army.mil/Portals/7/militaryreview/Archives/English/MilitaryReview_20091031_art011.pdf

Thorpe, N. (2019, JANUARY 10). Albania races to rescue children from jihadist camp. BBC. Retrieved June 2, 2021, from https://www.bbc.com/news/world-europe-55435069

Tota, E. (2017, Jamuary 27). 40 women from Kosovo are part of ISIS. IBNA. Retrieved June 4, 2021, from https://balkaneu.com/40-women-kosovopart-isis/

UN human rights office of the high commissioner. Syria: UN experts urge 57 States to repatriate women and children from squalid camps. (2021, February 8). Retrieved June 12, 2021, from https://www.ohchr.org/EN/NewsEvents/Pages/DisplayNews.aspx?Ne wsID $=26730 \&$ LangID $=\mathrm{E}$

UNHCR. (1951, 1967). Convention and Protocol Relating to the Status of Refugees. 14. Retrieved June 4, 2021, from https://www.unhcr.org/: https://www.unhcr.org/3b66c2aa10

Vanchoski A, S. N. (2020). Enhancing the Understanding of Foreign Terrorist Fighters (FTF):Challenges for Rehabilitation, Resocialization and Reintegration of Returnees in the Republic of North Macedonia. NEXUS Civil Concept. Retrieved June 9, 2021, from https://ctmorse.eu/resource/enhancing-the-understanding-of-foreign-terroristfighters-ftf-challenges-for-rehabilitation-resocialization-andreintegration-of-returnees-in-the-republic-of-north-macedonia/

Vurmo, G. (2018). EXTREMISMRESEARCHFORUM. British Council. Retrieved June 5, 2021, from https://www.britishcouncil.al/sites/default/files/erf20albania20report2 02018.pdf 